Article

\title{
Identification of Two New Phenanthrenes from Dendrobii Herba and Their Cytotoxicity towards Human Hypopharynx Squamous Carcinoma Cell (FaDu)
}

\author{
Bomi Nam ${ }^{1,2}$, Seung Mok Ryu ${ }^{3,4}$, Dongho Lee ${ }^{3}$, Chan-Hun Jung ${ }^{5}$, Chang Hyun Jin ${ }^{1}$, \\ Jin-Baek Kim ${ }^{1}$, Ik-Soo Lee ${ }^{2, *}$ and Ah-Reum Han ${ }^{1, * \mathbb{D}}$ \\ 1 Advanced Radiation Technology Institute, Korea Atomic Energy Research Institute, Jeongeup-si, \\ Jeollabuk-do 56212, Korea; bomi1201@kaeri.re.kr (B.N.); chjin@kaeri.re.kr (C.H.J.); \\ jbkim74@kaeri.re.kr (J.-B.K.) \\ 2 College of Pharmacy, Chonnam National University, Gwangju 61186, Korea \\ 3 Department of Biosystems and Biotechnology, Korea University, Seoul 02841, Korea; \\ smryu@kiom.re.kr (S.M.R.); dongholee@korea.ac.kr (D.L.) \\ 4 Herbal Medicine Resources Research Center, Korea Institute of Oriental Medicine, Naju-si, \\ Jeollanam-do 58245, Korea \\ 5 Department of Otolaryngology-Head \& Neck Surgery, School of Medicine, Kyung Hee University, \\ Seoul 02447, Korea; chjung@khu.ac.kr \\ * Correspondence: islee@chonnam.ac.kr (I.-S.L.); arhan@kaeri.re.kr (A.-R.H.); \\ Tel.: +82-62-530-2932 (I.-S.L.); +82-63-570-3167 (A.-R.H.)
}

Received: 28 May 2019; Accepted: 25 June 2019; Published: 25 June 2019

check for updates

\begin{abstract}
Two new phenanthrenes, (1R,2R)-1,7-hydroxy-2,8-methoxy-2,3-dihydrophenanthrene4(1H)-one (1) and 2,7-dihydroxy-phenanthrene-1,4-dione (2), were isolated from the ethyl acetate-soluble fraction of Dendrobii Herba, together with seven known phenanthrenes (3-9), two bibenzyls (10-12), and a lignan (13). Structures of 1 and 2 were elucidated by analyzing one-dimensional (1D) and two-dimensional (2D)-NMR and High-resolution electrospray ionization mass spectra (HR-ESI-MS) data. The absolute configuration of compound 1 was confirmed by the circular dichroism (CD) spectroscopic method. In cytotoxicity assay using FaDu human hypopharynx squamous carcinoma cell line, compounds 3-6, 8, 10, and 12 showed activities, with $\mathrm{IC}_{50}$ values that ranged from 2.55 to $17.70 \mu \mathrm{M}$.
\end{abstract}

Keywords: Dendrobii Herba; $(1 R, 2 R)-1,7-$ hydroxy-2,8-methoxy-2,3-dihydrophenanthrene-4(1H)-one; 2,7-dihydroxy-phenanthrene-1,4-dione; cytotoxicity; FaDu human hypopharynx squamous carcinoma cell

\section{Introduction}

Dendrobii Herba is a herbal medicine that uses stems of Dendrobium species (Orchidacea), such as D. nobile, D. chrysanthum, D. officinale, D. loddigessi, D. fimbriatum var. oculatum, D. moniliforme, or D. candidum $[1,2]$. It has been traditionally used to treat lower fever, dryness of throat, gastrodynia due to stomach problem, blurred vision, and atrophy of the tendon and bone due to kidney problems in East Asia [3-5]. Previous phytochemical studies on Dendrobium species have reported the isolation of various types of compounds, specifically phenanthrenes as major components [6-14]. Phenanthrenes have been reported to have anti-inflammatory [6-8], antifibrotic [9], anti-cancer [10-12], and antibacterial activities [13]. Bibenzyl compounds, including stilbenes, are also abundant in Dendrobium 
species [14-19] with diverse activities, such as antioxidant [14], anti-inflammatory [14], anti-migratory [15], retinal neoangiogenesis inhibitory [16], and antimutagenic [17,18] activities.

Head and neck cancer is a group of cancers that primarily originate in the lips, mouth, nasal cavity, sinuses, and larynx. Head and neck squamous cell carcinoma (HNSCC) accounts for most of the cancers of the head. It arises from the mucosal surface of this part [20]. The most common risk factors that are associated with head and neck cancer are alcohol and tobacco [21]. Around the world, over 550,000 cases of HNSCC and around 300,000 deaths have been annually reported [21]. Although clinical trials, including surgery, radiation therapy, and chemotherapy, have been conducted, five-year survival rate of HNSCC patients has not improved over the past few decades [20,21]. Natural products with apoptotic mechanism in HNSCC have been reported as part of the effort to develop chemotherapeutic agents for HNSCC [22,23].

During our screening procedure to find new bioactive compounds from plant sources, the ethyl acetate-soluble fraction of Dendrobii Herba exhibited considerable cytotoxicity against the FaDu human hypopharynx squamous carcinoma cell line, with an $\mathrm{IC}_{50}$ value of $13.16 \mu \mathrm{g} / \mathrm{mL}$. Therefore, it was subjected to detailed phytochemical investigation, affording 13 compounds, including two new phenanthrenes $\mathbf{1}$ and $\mathbf{2}$ (Figure 1). Herein, we describe the structural elucidation of $\mathbf{1}$ and $\mathbf{2}$ and the results of biological evaluation for compounds 1-13.

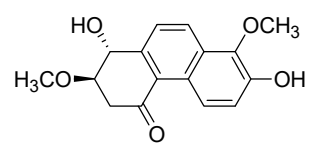

1

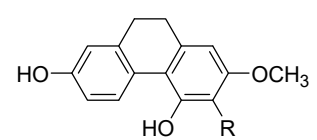

$8 \mathrm{R}=\mathrm{OCH}_{3}$ $9 \mathrm{R}=\mathrm{H}$
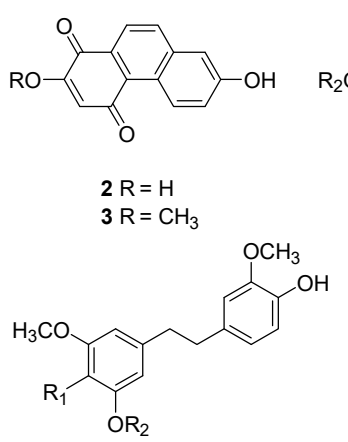

$10 \mathrm{R}_{1}=\mathrm{OH} \mathrm{R}=\mathrm{CH}_{3}$ $11 \mathrm{R}_{1}=\mathrm{HR}_{2}=\mathrm{H}$
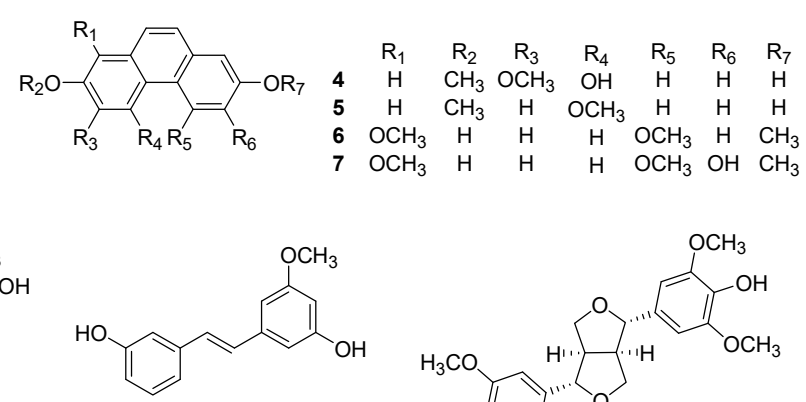

12

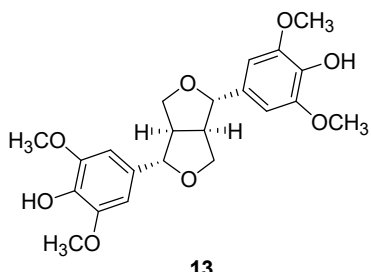

13

Figure 1. Chemical structures of compounds isolated from the ethyl acetate-soluble fraction of Dendrobii Herba.

\section{Results and Discussion}

\subsection{Structure Elucidation of Compounds $\mathbf{1}$ and $\mathbf{2}$}

Compound 1 was obtained as a brown solid with a molecular ion peak at $m / z 311.0891[\mathrm{M}+\mathrm{Na}]^{+}$ in high resolution electrospray ionization mass spectrum corresponding to an elemental formula of $\mathrm{C}_{16} \mathrm{H}_{16} \mathrm{O}_{5} \mathrm{Na}$. In the ${ }^{1} \mathrm{H}-\mathrm{NMR}$ spectrum of $\mathbf{1}$, two sets of ortho-coupled aromatic proton signals at $\delta_{\mathrm{H}} 8.99(1 \mathrm{H}, \mathrm{d}, J=9.0 \mathrm{~Hz}, \mathrm{H}-5), 8.32(1 \mathrm{H}, \mathrm{d}, J=8.8 \mathrm{~Hz}, \mathrm{H}-9), 7.73(1 \mathrm{H}, \mathrm{d}, J=8.8 \mathrm{~Hz}, \mathrm{H}-10)$, and $7.24(1 \mathrm{H}, \mathrm{d}, J=9.0 \mathrm{~Hz}, \mathrm{H}-6)$ showed the two fused benzene ring system (Table 1). Thus, it was supported by ${ }^{1} \mathrm{H}-{ }^{1} \mathrm{H}$ COSY NMR correlations of $\mathrm{H}-5 / \mathrm{H}-6$ and $\mathrm{H}-9 / \mathrm{H}-10$ and ${ }^{1} \mathrm{H}-{ }^{13} \mathrm{C}-\mathrm{HMBC}-\mathrm{NMR}$ correlations of H-5/C-7, C-8a, H-6/C-4b, C-7, C-8, H-9/C-4b, C-8, and H-10/C-8a (Figure 2). The ${ }^{1} \mathrm{H}$ and ${ }^{13} \mathrm{C}$-NMR spectra of 1 displayed signals for two oxygenated methine groups at $\delta_{\mathrm{H}} 4.88(1 \mathrm{H}, \mathrm{d}$, $J=8.5 \mathrm{~Hz}, \mathrm{H}-1) / \delta_{\mathrm{C}} 70.9(\mathrm{C}-1)$ and $3.79(1 \mathrm{H}, \mathrm{m}, \mathrm{H}-2) / 80.5(\mathrm{C}-2)$, a methylene group at $\delta_{\mathrm{H}} 3.22(1 \mathrm{H}$, $\mathrm{dd}, J=16.2,3.8 \mathrm{~Hz}, \mathrm{H}-3 \alpha)$, and $2.74(1 \mathrm{H}, \mathrm{dd}, J=16.2,8.5 \mathrm{~Hz}, \mathrm{H}-3 \beta) / \delta_{\mathrm{C}} 42.2(\mathrm{C}-3)$, and a carbonyl group at $\delta_{\mathrm{C}} 198.7(\mathrm{C}-4)$, representing a cyclohexanone ring that was linked to $\mathrm{C}-4 \mathrm{a}$ and $\mathrm{C}-10 \mathrm{a}$ in the naphthalene system by ${ }^{1} \mathrm{H}_{-}{ }^{13} \mathrm{C}-\mathrm{HMBC}-\mathrm{NMR}$ correlations of $\mathrm{H}-1 / \mathrm{C}-2, \mathrm{C}-4 \mathrm{a}, \mathrm{C}-10 \mathrm{a}, \mathrm{H}-3 / \mathrm{C}-1, \mathrm{C}-2$, C4, H-9/C-10a, and H-10/C-4a. Positions of two methoxy groups were assigned at C-2 and C-8, respectively, by ${ }^{1} \mathrm{H}_{-}{ }^{13} \mathrm{C}-\mathrm{HMBC}-\mathrm{NMR}$ correlations of $\mathrm{OCH}_{3} / \mathrm{C}-2$ and $\mathrm{OCH}_{3} / \mathrm{C}-8$. In addition, when comparing ${ }^{1} \mathrm{H}$ and ${ }^{13} \mathrm{C}-\mathrm{NMR}$ spectra of $\mathbf{1}$ with those of heliophenanthrene [24] indicated that the 
structure of 1 was similar to that of heliophenanthrene, except for the difference in signals of the aromatic ring system and functional groups. The trans stereochemistry between $\mathrm{H}-1$ and $\mathrm{H}-2$ was deduced by their large coupling constant $(J=8.5 \mathrm{~Hz})$. The absolute configuration of $\mathbf{1}$ at $\mathrm{C}-1$ and C-2 was assigned by comparing its experimental ECD spectrum to the calculated ECD spectra of two enantiomers $(1 R, 2 R)-\mathbf{1}$ and $(1 S, 2 S)-\mathbf{1}$ and determined as $(1 R, 2 R)$ due to the similarity of ECD spectrum of $\mathbf{1}$ with that of $(1 R, 2 R)-\mathbf{1}$ (Figure 3$)$. Therefore, the structure of compound $\mathbf{1}$ was elucidated as $(1 R, 2 R)-1,7$-hydroxy-2,8-methoxy-2,3-dihydrophenanthrene-4(1H)-one.

Table 1. ${ }^{1} \mathrm{H}-\mathrm{NMR}(500 \mathrm{MHz})$ and ${ }^{13} \mathrm{C}-\mathrm{NMR}(125 \mathrm{MHz})$ spectral data $\left(\mathrm{CD}_{3} \mathrm{OD}, \delta\right.$ in $\left.\mathrm{ppm}\right)$ of $\mathbf{1}$ and 2 isolated from Dendrobii Herba.

\begin{tabular}{|c|c|c|c|c|}
\hline \multirow{2}{*}{ Position } & \multicolumn{2}{|l|}{1} & \multicolumn{2}{|l|}{2} \\
\hline & $\delta_{\mathbf{H}}$ & $\delta_{C}$ & $\delta_{\mathbf{H}}$ & $\delta_{C}$ \\
\hline 1 & $4.88(4 \mathrm{H}, \mathrm{d}, J=8.5 \mathrm{~Hz})$ & 70.9 & & 180.9 \\
\hline 2 & $3.79(1 \mathrm{H}, \mathrm{m})$ & 80.5 & & 159.0 \\
\hline 3 & & & $6.18(1 \mathrm{H}, \mathrm{s})$ & 110.6 \\
\hline $3 \alpha$ & $3.22(1 \mathrm{H}, \mathrm{dd}, J=16.2,3.8 \mathrm{~Hz})$ & 42.2 & & \\
\hline $3 \beta$ & $2.74(1 \mathrm{H}, \mathrm{dd}, J=16.2,8.5 \mathrm{~Hz})$ & & & \\
\hline 4 & & 198.7 & & 188.8 \\
\hline 5 & $8.99(1 \mathrm{H}, \mathrm{d}, J=9.0 \mathrm{~Hz})$ & 123.3 & $9.41(1 \mathrm{H}, \mathrm{d}, J=9.3 \mathrm{~Hz})$ & 129.8 \\
\hline 6 & $7.24(1 \mathrm{H}, \mathrm{d}, J=9.0 \mathrm{~Hz})$ & 121.1 & $7.26(1 \mathrm{H}, \mathrm{dd}, J=9.3,2.0 \mathrm{~Hz})$ & 122.5 \\
\hline 7 & & 146.5 & & 158.7 \\
\hline 8 & & 140.1 & $7.14(1 \mathrm{H}, \mathrm{d}, J=2.0 \mathrm{~Hz})$ & 109.6 \\
\hline 9 & $8.32(1 \mathrm{H}, \mathrm{d}, J=8.8 \mathrm{~Hz})$ & 127.3 & $7.94(1 \mathrm{H}, \mathrm{d}, J=8.8 \mathrm{~Hz})$ & 131.8 \\
\hline 10 & $7.73(1 \mathrm{H}, \mathrm{d}, J=8.8 \mathrm{~Hz})$ & 125.8 & $8.03(1 \mathrm{H}, \mathrm{d}, J=8.8 \mathrm{~Hz})$ & 121.6 \\
\hline $4 a$ & & 126.0 & & 127.4 \\
\hline $4 b$ & & 129.6 & & 123.8 \\
\hline $8 a$ & & 125.4 & & 139.8 \\
\hline $10 \mathrm{a}$ & & 142.4 & & 128.3 \\
\hline $2-\mathrm{OCH}_{3}$ & $3.47(3 \mathrm{H}, \mathrm{d}, J=1.5 \mathrm{~Hz})$ & 56.2 & & \\
\hline $8-\mathrm{OCH}_{3}$ & $3.91(3 \mathrm{H}, \mathrm{d}, J=1.5 \mathrm{~Hz})$ & 60.2 & & \\
\hline
\end{tabular}

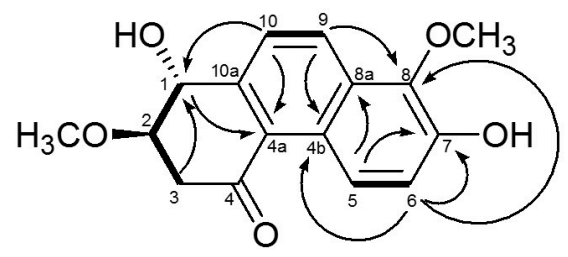

1

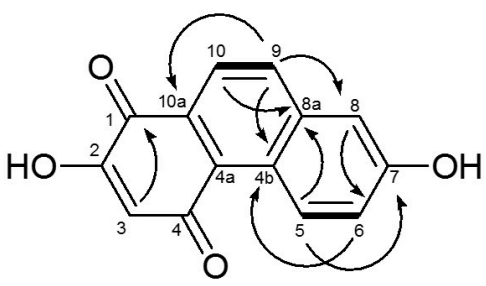

Figure 2. Key ${ }^{1} \mathrm{H}_{-}{ }^{1} \mathrm{H} \operatorname{COSY}(-)$ and ${ }^{1} \mathrm{H}_{-}{ }^{13} \mathrm{C}-\mathrm{HMBC}-(\rightarrow)$ correlations of $\mathbf{1}$ and 2.

(A)

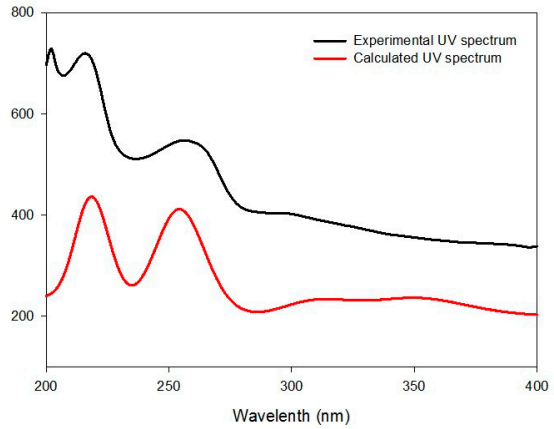

(B)

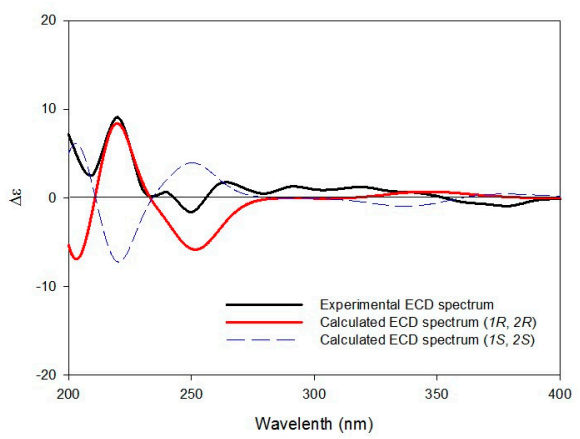

Figure 3. (A) Experimental and calculated UV spectra of $\mathbf{1}$ and (B) Experimental ECD spectra of $\mathbf{1}$ and the calculated ECD spectra of $(1 R, 2 R)-\mathbf{1}$ and $(1 S, 2 S)-\mathbf{1}$. 
Compound 2 was obtained as a brown solid with a molecular ion peak at $m / z 239.0346[\mathrm{M}-\mathrm{H}]^{-}$in high resolution electrospray ionization mass spectrum, which is consistent with an elemental formula of $\mathrm{C}_{14} \mathrm{H}_{7} \mathrm{O}_{4}$. The ${ }^{1} \mathrm{H}$ spectrum of 2 displayed signals for a 1,2,4-trisubstituted aromatic ring system at $\delta_{\mathrm{H}} 9.41(1 \mathrm{H}, \mathrm{d}, J=9.3 \mathrm{~Hz}, \mathrm{H}-5), 7.26(1 \mathrm{H}, \mathrm{dd}, J=9.3,2.0 \mathrm{~Hz}, \mathrm{H}-7)$ and $7.14(1 \mathrm{H}, \mathrm{d}, J=2.0, \mathrm{H}-8)$, ortho-coupled aromatic protons at $\delta_{\mathrm{H}} 7.94(1 \mathrm{H}, \mathrm{d}, J=8.8 \mathrm{~Hz}, \mathrm{H}-9)$, and $8.03(1 \mathrm{H}, \mathrm{d}, J=8.8 \mathrm{~Hz}, \mathrm{H}-10)$, and an aromatic proton singlet at $\delta_{\mathrm{H}} 6.18(1 \mathrm{H}, \mathrm{s}, \mathrm{H}-2)$. The ${ }^{13} \mathrm{C}$ spectrum of 2 showed signals for two conjugated carbonyl carbons at $\delta_{C} 180.9$ (C-1) and 188.8 (C-4) (Table 1). These NMR data suggest that 2 has a phenathrenedione structure. This was supported by the ${ }^{1} \mathrm{H}-{ }^{13} \mathrm{C}-\mathrm{HMBC}-\mathrm{NMR}$ correlations of H-3/C-1, H-5/C-7, C-8a, H-6/C-4b, H-8/C-6, H-9/C-4b, C-8, C-10a, and H-10/C-8a (Figure 2). The few three bond correlations observed in the ${ }^{1} \mathrm{H}-{ }^{13} \mathrm{C}-\mathrm{HMBC}-\mathrm{NMR}$ spectrum of 2 did not allow for unambiguous assignment of ${ }^{13} \mathrm{C}$ resonance at C-2 or C-3. However, further comparison of ${ }^{13} \mathrm{C}-\mathrm{NMR}$ data of two carbonyl groups with published values in 1,4-phenanthrenedione structure $[14,25,26]$ confirmed that two carbonyl carbon signals at $\delta_{C} 180.9$ and $\delta_{C} 188.8$ could be assigned to $C-1$ and C-4, respectively. Accordingly, the position of a hydroxyl group in the 1,4-benzoquinone moiety was determined as C-2 by three-bond correlation from the aromatic proton signal at $\delta_{\mathrm{H}} 6.18(1 \mathrm{H}, \mathrm{s}, \mathrm{H}-2)$ to the carbonyl carbon signal at $\delta_{C} 180.9$ (C-1). Another hydroxyl group was attached at C-7, as evidenced by the ${ }^{1} \mathrm{H}-{ }^{13} \mathrm{C}-\mathrm{HMBC}-\mathrm{NMR}$ correlations of $\mathrm{H}-5 / \mathrm{C}-7$. Furthermore, the ${ }^{1} \mathrm{H}$ and ${ }^{13} \mathrm{C}$ spectra (in DMSO- $d_{6}$ ) of 2 showed almost identical signals to those of 3 [14], except for the absence of signals for a methoxy group at $\delta_{\mathrm{H}} 3.86\left(3 \mathrm{H}, \mathrm{s}, 2-\mathrm{OCH}_{3}\right) / \delta_{\mathrm{C}} 57.0\left(\mathrm{OCH}_{3}\right)$ in 3 (Supplementary Materials Table S1). Therefore, its structure was determined to be 2,7-dihydroxy-phenanthrene-1,4-dione.

The eleven known compounds were identified as densiflorol B (3) [14], 6,7-dimethoxyphenanthrene-2,5-diol (4) [27], dehydroorchinol (5) [8], 1,5,7-trimethoxy-2-phenanthrenol (6) [8], denthyrsinin (7) [28], ephemeranthol A (8) [29], lusianthridin (9) [30], moscatilin (10) [18], gigantol (11) [12], 3-[(1E)-2-(3-Hydroxyphenyl)ethenyl]-5-methoxyphenol (12) [31], and (-)-syringaresinol (13) [19] by comparing their spectroscopic data with the published data (Supplementary Materials Figures S11-S32). Although the known compounds (3-11 and 13) have been isolated from Dendrobium species, the isolation of compound 12 from Dendrobium species has not been reported yet.

\subsection{Biological Activity}

The ethanol extract and solvent fractions of Dendrobii Herba primarily tested their cytotoxic activities on human pharynx squamous carcinoma $(\mathrm{FaDu})$ cell line. The ethanol extract showed the activity with $\mathrm{IC}_{50}$ value of $16.57 \mu \mathrm{g} / \mathrm{mL}$. It was successively partitioned with hexanes, ethyl acetate, and $n$-butanol, and these solvent fractions exhibited their cytotoxicities with $\mathrm{IC}_{50}$ values of $14.51,13.16$, and $13.67 \mu \mathrm{g} / \mathrm{mL}$, respectively (Supplementary Materials Figure S33). The most active fraction, the ethyl acetate fraction, was subjected to detailed laboratory investigation in order to isolate the active compounds. All of the isolates were evaluated for their cytotoxicities to FaDu cell line and, of them, compounds 3-6, 8, 10, and 12 exhibited cytotoxicities with $\mathrm{IC}_{50}$ values of 15.91, 11.40, 17.33, 17.70, 17.03, 2.55 , and $17.14 \mu \mathrm{M}$, respectively (Supplementary Materials Figure S34). Cisplatin as a positive control showed an $\mathrm{IC}_{50}$ value of $1.18 \mu \mathrm{M}$. The structural differences influenced the potency of cytotoxicity. In broad outlines, the methylation of the free hydroxyl groups and the presence of additional oxygenated groups in both aromatic rings in each skeleton group, phenanthrene (3-6), 9,10-dihydrophenanthrene (8), or bibenzyl (10) were deduced to be more active. Of these active compounds, compound 10 showed the strongest cytotoxicity. Previous studies regarding the anticancer activities of $\mathbf{1 0}$ have reported that $\mathbf{1 0}$ can induce apoptosis of human pancreatic cancer cells though reactive oxygen species (ROS) and the c-Jun N-terminal kinase/stress-activated protein kinase (JNK/SAPK) pathway [32], apoptosis of human esophageal cancer cells by G2/M arrest and protein regulating mitosis [33], and the apoptosis of human colorectal cancer cells via JNK activation by tubulin depolymerization and DNA damage [34]. There are also reports on the regulation of tumor cell metastasis by 10. For example, it has been reported that compound $\mathbf{1 0}$ can inhibit lung cancer cell migration and invasion through the suppression of ROS and focal adhesion kinase/protein kinase B (FAK/Akt) activation [35]. It can also inhibit breast cancer 
cell migration by inhibiting Akt/Twist [36]. In addition, compound $\mathbf{1 0}$ has an anti-angiogenesis effect on human umbilical vein endothelial cells via Extracellular signal-regulated kinases (ERK1/2), Akt, and endothelial nitric oxide synthase (eNOS) signaling pathways [37]. However, to the best of our knowledge, there has been no report of an anticancer mechanistic study of compound $\mathbf{1 0}$ in HNSCC, including FaDu cells. Thus, $\mathbf{1 0}$ could be beneficial for treating human pharynx squamous cancer. However, further studies are needed to determine its mechanism of action while using in vitro and in vivo models.

\section{Materials and Methods}

\subsection{General Procedures}

Optical rotations were measured on a JASCO P-2000 polarimeter (JASCO Co., Tokyo, Japan). Circular dichroism (CD) measurements were performed while using a JASCO J-810 CD-ORD spectropolarimeter (JASCO Co., Tokyo, Japan). One-dimensional (1D) and two-dimensional (2D)-NMR experiments were performed on a JM-ECA $500 \mathrm{MHz}$ NMR instrument (JEOL Ltd., Tokyo, Japan) with tetramethylsilane (TMS) as the internal standard. High-resolution electrospray ionization mass spectra (HR-ESI-MS) were recorded on a Waters SYNAPT G2 mass spectrometer (Waters, Milford, MA, USA). Silica gel (70-230 mesh, Merck, Darmstadt, Germany), RP-18 (YMC gel ODS-A, $12 \mathrm{~nm}$, S-75 $\mu \mathrm{m}$, YMC Co., Tokyo, Japan), and Sephadex LH-20 (GE Healthcare Bio-Sciences, Uppsala, Sweden) were used for column chromatography (CC). Thin-layer chromatographic (TLC) analysis was performed on Kieselgel $60 \mathrm{~F}_{254}$ (Merck, Darmstadt, Germany) and Kieselgel 60 RP-18-F254S (Merck, Darmstadt, Germany), with visualization under UV light $(254$ and $365 \mathrm{~nm})$ and $10 \%(v / v)$ sulfuric acid spray, followed by heating at $180^{\circ} \mathrm{C}$ for $2 \mathrm{~min}$. YMC-Pack Pro C18 column $(5 \mu \mathrm{m}, 250 \mathrm{~mm} \times 20 \mathrm{~mm}$ i.d., YMC Co., Tokyo, Japan) was used for preparative high performance liquid chromatography (HPLC) that was conducted on a Gilson Preparative HPLC system (Gilson Inc., Middleton, WI, USA). Medium pressure liquid chromatography (MPLC) was performed on a CombiFlash Rf200 system (Teledyne ISCO, Lincoln, NE, USA) with RediSep Rf Normal Phase Silica columns. Analytical HPLC-DAD was carried out on an Agilent 1200 series system (Agilent Technologies Co., Santa Clara, CA, USA) that was equipped with a YMC-Triart C18 column ( $5 \mu \mathrm{m}, 250 \mathrm{~mm} \times 4.6 \mathrm{~mm}$, YMC Co., Tokyo, Japan).

\subsection{Plant Material}

Dendrobii Herba stems (CK PHARM Co., Ltd., Seoul, Korea) were purchased from the Jewondang herb shop in Jeongup-si, Jeollabuk-do, Korea. Voucher specimens (accession no. TM007) were deposited at the Advanced Radiation Technology Institute, Korea Atomic Energy Research Institute. HPLC-DAD analysis was performed on its ethanol extract and solvent fractions to confirm the quality of this plant material (Supplementary Materials Figure S35).

\subsection{Extraction and Isolation}

Dried stems ( $5 \mathrm{~kg}$ ) of Dendrobii Herba were extracted with $95 \% \mathrm{EtOH}(5 \times 14 \mathrm{~L})$ overnight at room temperature. The solvent was evaporated in vacuo to afford a $95 \% \mathrm{EtOH}$ extract (122 g), which was then suspended in distilled water $(1 \mathrm{~L})$ and partitioned with hexanes $(3 \times 1 \mathrm{~L})$, ethyl acetate $(5 \times 1 \mathrm{~L})$, and $n$-butanol $(2 \times 1 \mathrm{~L})$ sequentially. The EtOAc-soluble fraction $(35 \mathrm{~g})$ was then subjected to silica gel column chromatography (CC) while using a radient solvent system of $\mathrm{CHCl}_{3}-\mathrm{MeOH}$ (1:0 to 0:1, $v / v)$ to afford 16 fractions (F01-F16). Fraction F03 (0.7 g) was subjected to reverse-phase CC with a solvent system of $\mathrm{MeOH}-\mathrm{H}_{2} \mathrm{O}$ (1:2 to 1:0, v/v), affording 15 subfractions (F0301-F0315). Subfraction F0311 (250 mg) was purified by MPLC (hexane-EtOAc, $85: 15,15 \mathrm{~mL} / \mathrm{min}$ ) to yield $8(6 \mathrm{mg})$. Subfraction F0312 (115 mg) was chromatographed on a Sephadex LH-20 column while using 100\% MeOH to give 7 (56 mg) and $10(14 \mathrm{mg})$. Subfraction F0314 $(80 \mathrm{mg}$ ) was separated by MPLC (heaxen-EtOAc, 9:1 to 85:15, $15 \mathrm{~mL} / \mathrm{min}$ ), affording two subfractions (F031401 and F031402). Purified F031401 was subjected to Sephadex $\mathrm{LH}-20 \mathrm{CC}$ while using $\mathrm{CHCl}_{3}-\mathrm{MeOH}(1: 1, v / v)$ to obtain $6(1 \mathrm{mg})$ and $5(2.5 \mathrm{mg})$. Fraction $\mathrm{F}$ 
$04(6 \mathrm{~g})$ was subjected to silica gel CC with a solvent system of $\mathrm{CHCl}_{3}-\mathrm{MeOH}(9.5: 0.5$ to 1:1, v/v), which afforded ten subfractions (F0401-F0412). Subfraction F0404 (0.9 g) was subjected to reverse-phase $\mathrm{CC}$ with solvent system of $\mathrm{MeOH}-\mathrm{H}_{2} \mathrm{O}$ (1:1 to 1:0, v/v), affording 20 subfractions (F040401-F040420). Subfraction F040412 was chromatographed on a Sephadex LH-20 column while using 100\% MeOH to give 4 (3 mg). Fraction F07 (3 g) was subjected to silica gel CC with solvent system of heaxen-EtOAc (9:1 to 85:15, v/v), affording ten subfractions (F0701-F0710). Subfraction F0703 (126 mg) was subjected to Sephadex LH-20 CC while using 100\% MeOH to give five subfractions (F070301-F070305). Subfraction F070305 (50 mg) was chromatographed on a Sepadex LH-20 column using 100\% MeOH to give four subfractions (F07030501-F07030504). The fourth fraction (20 mg) was purified by reverse-phase CC with a gradient solvent system of $\mathrm{MeOH}-\mathrm{H}_{2} \mathrm{O}(1: 1$ to $4: 1, v / v)$ to yield 9 (10 mg). Subfraction F0704 (270 mg) was subjected to reverse-phase CC while using $\mathrm{MeOH}-\mathrm{H}_{2} \mathrm{O}$ (1:1 to 1:0, v/v), producing 20 subfractions (F070401-F070420). Subfraction F070414 (14 mg) was chromatographed on a Sephadex LH-20 column while using $\mathrm{CHCl}_{3}-\mathrm{MeOH}(1: 1, v / v)$ to give four fractions (F07041401-F07041404). F07041402 and F07041403 were purified by preparative HPLC (MeOH-H ${ }_{2} \mathrm{O}, 8: 2,3 \mathrm{~mL} / \mathrm{min}$ ) to afford 11 $\left(2 \mathrm{mg}, t_{\mathrm{R}} 22.5 \mathrm{~min}\right)$ and $3\left(1.6 \mathrm{mg}, t_{\mathrm{R}} 29.8 \mathrm{~min}\right) .2\left(2 \mathrm{mg}, t_{R} 32.5 \mathrm{~min}\right)$ was obtained by preparative HPLC with $\left(\mathrm{MeOH}-\mathrm{H}_{2} \mathrm{O}, 7.5: 2.5,3 \mathrm{~mL} / \mathrm{min}\right)$. Subfraction F070416 (23 mg) was separated by Sephadex LH-20 $\mathrm{CC}$ using 50\% $\mathrm{MeOH}$ in $\mathrm{CHCl}_{3}$ to give four subfractions (F07041601-F07041604). F07041601 (3.8 mg) was purified by preparative HPLC (MeOH- $\left.\mathrm{H}_{2} \mathrm{O}, 7: 3,3 \mathrm{~mL} / \mathrm{min}\right)$ to afford $12\left(2.8 \mathrm{mg}, t_{\mathrm{R}} 40.3 \mathrm{~min}\right)$. F07041602 (3 mg) was purified by preparative HPLC $\left(\mathrm{MeOH}-\mathrm{H}_{2} \mathrm{O}, 7: 3,3 \mathrm{~mL} / \mathrm{min}\right)$ to obtain $13(1.5 \mathrm{mg}$, $\left.t_{\mathrm{R}} 36 \mathrm{~min}\right)$. Subfraction F0707 (120 mg) was subjected to reverse-phase CC using $\mathrm{MeOH}-\mathrm{H}_{2} \mathrm{O}(1: 1$ to $1: 0, v / v)$, affording 12 subfractions (F070701-F070712). The second subfraction was then purified by Sephadex LH-20 CC while using 100\% MeOH to afford 1 (10 mg).

$(1 R, 2 R)-1,7-h y d r o x y-2,8-m e t h o x y-2,3-d i h y d r o p h e n a n t h r e n e-4(1 H)$-one (1): Brown solid. $[\alpha]_{D}^{20}$ $-8.83^{\circ}$ (c 0.03, MeOH). ${ }^{1} \mathrm{H}(500 \mathrm{MHz})$ and ${ }^{13} \mathrm{C}(125 \mathrm{MHz})$ data $\left(\mathrm{CD}_{3} \mathrm{OD}\right)$, see Table 1 . HR-ESI-MS (positive ions) $m / z 311.0891[\mathrm{M}+\mathrm{Na}]^{+}$(calculated for $\mathrm{C}_{16} \mathrm{H}_{16} \mathrm{O}_{5} \mathrm{Na}$, 311.0895).

2,7-dihydroxy-phenanthrene-1,4-dione (2): Brown solid. ${ }^{1} \mathrm{H}(500 \mathrm{MHz})$ and ${ }^{13} \mathrm{C}(125 \mathrm{MHz})$ data $\left(\mathrm{CD}_{3} \mathrm{OD}\right)$, see Table 1. HR-ESI-MS (negative ions) $\mathrm{m} / \mathrm{z} 239.0399[\mathrm{M}-\mathrm{H}]^{-}$(calculated for $\left.\mathrm{C}_{14} \mathrm{H}_{7} \mathrm{O}_{4}, 239.0344\right)$.

\subsection{Computational Method}

Conformer distributions, optimizations, and ECD calculations of compound 1 were carried out, as described previously [32]. Briefly, a conformer distribution was performed Spartan'14 software (Wave-function, Inc., Irvine, CA, USA) while using an MMFF force field. These conformers were optimized at DFT [B3LYP functional/6-31+G(d,p) basis set] level. ECD calculations were carried out at TDDFT (CAM-B3LYP/SVP basis set) level with a CPCM solvent model in MeCN using Gaussian 09 software (Gaussian, Inc., Wallingford, CT, USA). The calculated ECD spectra were simulated using SpecDis 1.64 software (University of Wuerzburg, Wuerzburg, Germany) with a half bandwidth of $0.3 \mathrm{eV}$. ECD curves of these conformers were weighted by the Boltzmann distribution.

\subsection{HPLC Analysis}

The ethanol extract and solvent fractions of Dendrobii Herba were accurately weighed and dissolved in $\mathrm{MeOH}$ at $2 \mathrm{mg} / \mathrm{mL}$. The sample solution was filtered through a syringe filter $(0.45 \mu \mathrm{m})$ for HPLC analysis. The standards were accurately weighed and dissolved in $\mathrm{MeOH}$ at $1.0 \mathrm{mg} / \mathrm{mL}$ for co-injection with each sample. Analysis of the chemical composition of the sample was conducted while using the Agilent 1200 series LC system with an YMC-Triart C18 column $(5 \mu \mathrm{m}, 250 \mathrm{~mm} \times 4.6 \mathrm{~mm}$, YMC Co.). Binary gradient elution with water (solvent A) and acetonitrile (solvent B) was performed, as follows: $0-5 \mathrm{~min}, 20 \% \mathrm{~B}$; 5-45 $\mathrm{min}, 20-70 \% \mathrm{~B} ; 45-46 \mathrm{~min}, 70-100 \% \mathrm{~B} ; 46-56 \mathrm{~min}, 100 \% \mathrm{~B} ; 56-57 \mathrm{~min}$, and $100-20 \% \mathrm{~B} ; 57-60 \mathrm{~min}, 20 \% \mathrm{~B}$. The total flow rate was maintained at $1 \mathrm{~mL} / \mathrm{min}$ and the injection volume was $10 \mu \mathrm{L}$. Chromatograms were acquired at 230, 254, and $280 \mathrm{~nm}$ by the DAD detector. 


\subsection{Cytotoxicity Assay}

FaDu human pharynx squamous carcinoma cells were purchased from the Korean cell line bank (Seoul, Korea). All of the experiments were conducted with low-passage cell cultures ( $<$ passage 10). These cells were cultured in Minimum Essential Medium (MEM; Corning, Manassas, VA, USA) that was supplemented with 10\% heat-inactivated FBS (Hyclone, Logan, UT, USA) in a humidified incubator with $5 \% \mathrm{CO}_{2}$ at $37^{\circ} \mathrm{C}$. To determine viability of FaDu cells, the CCK-8 assay kit (Dojindo, Kumamoto, Japan) was used according to the manufacture's protocols. Briefly, the FaDu cells were seeded into 96-well plates at a density of $0.2 \times 10^{5}$ cells $/ \mathrm{mL}$ and incubated at $37^{\circ} \mathrm{C}$ for $24 \mathrm{~h}$. After incubation, the cultured $\mathrm{FaDu}$ cells were treated with the indicated concentration of each compound $(0.47-30 \mu \mathrm{M})$ and each extract $(1.5625-100 \mu \mathrm{g} / \mathrm{mL})$ for $72 \mathrm{~h}$. Thereafter, $10 \mu \mathrm{L}$ of CCK-8 reagent was added into cultured FaDu cells and then incubated for a further $4 \mathrm{~h}$ and absorbance was measured at $450 \mathrm{~nm}$ while using an SPARK ${ }^{\circledR}$ multimode microplate reader (Tecan, Männedorf, Switzerland). Afterwards, $50 \%$ inhibitory concentration $\left(\mathrm{IC}_{50}\right)$ was calculated from a dose-response analysis that was performed with GrahPad Prism software (GaraphPad Software, La Jolla, CA, USA).

\section{Conclusions}

Phytochemical study of Dendrobii Hereba resulted in isolation of two new phenanthrenes, $\quad(1 R, 2 R)-1,7$-hydroxy-2,8-methoxy-2,3-dihydrophenanthrene-4(1H)-one (1) and 2,7-dihydroxy-phenanthrene-1,4-dione (2). Of the 11 known compounds, compound 12 was isolated from Dendrobium species for the first time in this study. Compounds 3-6, 8, 10, and 12 showed cytotoxicity to the FaDu cells, with moscatilin (10) exhibiting remarkable cytotoxic activity. Further mechanistic studies are needed to determine the anticancer action of $\mathbf{1 0}$ against head and neck cancers while using in vitro and in vivo models.

Supplementary Materials: The supplementary materials are available online.

Author Contributions: Conceptualization, B.N. and A.-R.H.; methodology, B.N., A.-R.H., S.M.R., D.L. and C.-H.J.; software, B.N., S.M.R. and C.-H.J.; validation, B.N., S.M.R. and C.-H.J.; formal analysis, B.N., S.M.R. and C.-H.J.; investigation, B.N., S.M.R. and C.-H.J.; resources, J.-B.K. and C.H.J.; data curation, B.N., S.M.R. and C.-H.J.; writing—original draft preparation, B.N. and A.-R.H.; writing-review and editing, B.N. and A.-R.H.; visualization, B.N. and S.M.R.; supervision, I.-S.L. and A.-R.H.; project administration, J.-B.K. and C.H.J.; funding acquisition, J.-B.K. and C.H.J.

Funding: This work was supported by grants from the Korea Atomic Energy Research Institute (KAERI) and the National Research Foundation of Korea (2017R1C1B2006273).

Acknowledgments: The authors are thankful to the Korea basic Science Institute (KBSI), Ochang, Korea, for the measurement of HRESI mass spectra.

Conflicts of Interest: The authors declare no conflict of interest.

\section{References}

1. Lam, Y.; Ng, T.B.; Yao, R.M.; Shi, J.; Xu, K.; Sze, S.C.W.; Zhang, K.Y. Evaluation of chemical constituents and important mechanism of pharmacological biology in Dendrobium plants. Evid.-Based Complement. Altern. Med. 2015, 2015, 841752. [CrossRef] [PubMed]

2. Gu, C.; Zhang, X.; Wu, L.; Jiang, X.; Huang, L. Quality evaluation of Dendrobium based on ultra-performance liquid chromatography (UPLC) and chemometrics. J. Appl. Pharm. Sci. 2017, 7, 17-23. [CrossRef]

3. Ye, Z.; Dai, J.-R.; Zhang, C.-G.; Lu, Y.; Wu, L.-L.; Gong, A.G.W.; Xu, H.; Tsim, K.W.K.; Wang, Z.-T. Chemical differentiation of Dendrobium officinale and Dendrobium devonianum by using HPLC fingerprints, HPLC-ESI-MS, and HPTLC analyses. Evid.-Based Complement. Altern. Med. 2017, 2017, 8647212. [CrossRef] [PubMed]

4. Yoo, S.-R.; Jeong, S.-J.; Lee, N.-R.; Shin, H.-K.; Seo, C.-S. Simultaneous determination and anti-inflammatory effects of four phenolic compounds in Dendrobii herba. Nat. Prod. Res. 2017, 31, 2923-2926. [CrossRef] [PubMed] 
5. Xu, J.; Han, Q.-B.; Li, S.-L.; Chen, X.-J.; Wang, X.-N.; Zhao, Z.-Z.; Chen, H.-B. Chemistry, bioactivity and quality control of Dendrobium, a commonly used tonic herb in traditional Chinese medicine. Phytochem. Rev. 2013, 12, 341-367. [CrossRef]

6. Hwang, J.S.; Lee, S.A.; Hong, S.S.; Han, X.H.; Lee, C.; Kang, S.J.; Lee, D.; Kim, Y.; Hong, J.T.; Lee, M.K.; et al. Phenanthrenes form Dendrobium nobile and their inhibition of the LPS-induced production of nitric oxide in macrophage RAW 264.8 cells. Bioorg. Med. Chem. Lett. 2010, 20, 3785-3787. [CrossRef] [PubMed]

7. Lin, Y.; Wang, F.; Yang, L.-J.; Chun, Z.; Bao, J.-K.; Zhang, G.-L. Anti-inflammatory phenanthrene derivatives from stems of Dendrobium denneanum. Phytochemistry 2013, 95, 242-251. [CrossRef] [PubMed]

8. Kim, J.H.; Oh, S.-Y.; Han, S.-B.; Uddin, G.M.; Kim, C.Y.; Lee, J.K. Anti-inflammatory effects of Dendrobium nobile derived phenanthrenes in LPS-stimulated murine macrophages. Arch. Pharm. Res. 2015, 38, 1117-1126. [CrossRef] [PubMed]

9. Yang, H.; Sung, S.H.; Kim, Y.C. Antifibrotic penanthrenes of Dendrobium noble stems. J. Nat. Prod. 2007, 70, 1925-1959. [CrossRef]

10. Zhou, X.-M.; Zheng, C.-J.; Gan, L.-S.; Chen, G.-Y.; Zhang, X.-P.; Song, X.-P.; Li, G.-N.; Sun, C.-G. Bioactive phenanthrene and bibenzyl derivatives from the stems of Dendrobium nobile. J. Nat. Prod. 2016, 79, 1791-1797. [CrossRef]

11. Zhao, G.-Y.; Deng, B.-W.; Zhang, C.-Y.; Cui, Y.-D.; Bi, J.-Y.; Zhang, G.-G. New phenanthrene and 9, 10-dihydrophenanthrene derivatives from the stems of Dendrobium officinale with their cytotoxic activities. J. Nat. Med. 2018, 72, 246-251. [CrossRef] [PubMed]

12. Klongkumnuankarn, P.; Busaranon, K.; Chanvorachote, P.; Sritularak, B.; Jongbunprasert, V.; Likhitwitauawuid, K. Cytotoxic and antimigratory activities of phenolic compound from Dendrobium brymerianum. Evid.-Based Complement. Altern. Med. 2015, 2015, 350410. [CrossRef] [PubMed]

13. Chen, X.-J.; Mei, W.-L.; Zuo, W.-J.; Zeng, Y.-B.; Guo, Z.-K.; Song, X.Q. A new antibacterial phenanthrenequinone from Dendrobium sinense. J. Asian Nat. Prod. Res. 2013, 15, 67-70. [CrossRef] [PubMed]

14. Fan, C.; Wang, W.; Wang, Y.; Qin, G.; Zhao, W. Chemical constituents from Dendrobium densiflorum. Phytochemistry 2001, 57, 1255-1258. [CrossRef]

15. Charoenrungruang, S.; Chanvorachote, P.; Sritularak, B.; Pongrakhananon, V. Gigantol, a bibenzyl from Dendrobium draconis, inhibits the migratory behavior of non-small cell lung cancer cells. J. Nat. Prod. 2014, 77, 1359-1366. [CrossRef] [PubMed]

16. Yu, Z.; Zhang, T.; Gong, C.; Sheng, Y.; Lu, B.; Zhou, L.; Ji, L.; Wang, Z. Erianin inhibits high glucose-induced retinal angiogenesis via blocking ERK1/2-regulated HIF-1 $\alpha$-VEGF/VEGFR2 signaling pathway. Sci. Rep. 2016, 6, 1-15. [CrossRef] [PubMed]

17. Miyazawa, M.; Shimamura, H.; Nakamura, S.-I.; Kameoka, H. Antimutagenic activity of gigantol from Dendrobium nobile. J. Agric. Food Chem. 1997, 45, 2849-2853. [CrossRef]

18. Miyazawa, M.; Shimamura, H.; Nakamura, S.-I.; Sugiura, W.; Kosaka, H.; Kameoka, J. Moscatilin from Dendrobium nobile, a naturally occurring bibenzyl compound with potential antimutagenic activity. J. Agric. Food Chem. 1999, 47, 2163-2167. [CrossRef]

19. Chen, Y.; Yu, H.; Lian, X. Isolation of stilbenoids and lignans from Dendrobium hongdie. Trop. J. Pharm. Res. 2015, 14, 2055-2059. [CrossRef]

20. Leemans, C.R.; Braakhuis, B.J.; Brakenhoff, R.H. The molecular biology of head and neck cancer. Nat. Rev. Cancer 2011, 11, 9-22. [CrossRef]

21. Pezzuto, F.; Buonaguro, L.; Caponigro, F.; Ionna, F.; Starita, N.; Annunziata, C.; Buonaguro, F.M.; Tornesello, M.L. Update on head and neck cancer: Current knowledge on epidemiology, risk factors, molecular features and novel therapies. Oncology 2015, 89, 125-136. [CrossRef] [PubMed]

22. Park, M.R.; Kim, S.G.; Cho, I.A.; Oh, D.; Kang, K.R.; Lee, S.Y.; Moon, S.M.; Cho, S.S.; Yoon, G.; Kim, C.S.; et al. Licochalcone-A induces intrinsic and extrinsic apoptosis via ERK1/2 and p38 phosphorylation-mediated TRAIL expression in head and neck squamous carcinoma FaDu cells. Food Chem. Toxicol. 2015, 77, $34-43$. [CrossRef] [PubMed]

23. Seo, Y.S.; Yim, M.J.; Kim, B.H.; Kang, K.R.; Lee, S.Y.; Oh, J.S.; You, J.S.; Kim, S.G.; Yu, S.J.; Lee, G.J.; et al. Berberine-induced anticancer activities in FaDu head and neck squamous cell carcinoma cells. Oncol. Rep. 2015, 34, 3025-3034. [CrossRef] [PubMed] 
24. Gulet, D.; Guntern, A.; Isoet, J.-B.; Queiroz, E.F.; Ndjoko, K.; Foggin, C.M.; Hostettmann, K. Absolute configuration of a tetrahydrophenanthrene from Heliotropium ovalifolium by LC-NMR of its mosher esters. J. Nat. Prod. 2003, 66, 17-20. [CrossRef] [PubMed]

25. Chen, D.-N.; Wu, Y.-P.; Juan, Y.-J.; Liu, W.-J.; Wang, J.-J.; He, F.; Jiang, L. Two new stilbenoids from aerial part of Flickingeria fimbriata. J. Asian Nat. Prod. Res. 2017, 21, 117-122. [CrossRef]

26. Chen, Y.; Su, J.; Qing, C.; Zhang, Y.; Wnag, L.; Liu, Y.; Wang, J. Cytotoxic phenolics from Bulbophyllum odoratissimum. Food Chem. 2008, 107, 169-173. [CrossRef]

27. Tezuka, Y.; Hirano, H.; Kikuchi, T.; Xu, G.-J. Constituents of Ephemerantha lonchophylla; Isolation and structure elucidation of new phenolic compounds, ephemeranthol-A, ephemeranthol-B, and ephemeranthoquinone, and of a new diterpene glicoside, dphemeranthoside. Chem. Pharm. Bull. 1991, 39, 593-598. [CrossRef]

28. Majumder, P.L.; Sen, R.C. Pendulin, a polyoxygenated phenanthrene derivative from the orchid Cymbidium pendulum. Phytochemistry 1991, 30, 2432-2434. [CrossRef]

29. Wu, Y.-P.; Liu, W.-J.; Zhong, W.-J.; Chen, Y.-J.; Chen, D.-N.; He, F.; Jiang, L. Phenolic compounds from the stems of Flickingeria fimbriata. Nat. Prod. Res. 2017, 31, 1518-1522. [CrossRef]

30. Yan, H.-G.; Zhao, H.-R.; Hu, J.; Lu, A.-M.; Fu, X.-M.; Jia, B.; Yang, M.-H. Determination of phenanthrenes and stilbenoid in the ethyl acetate extract of Thunia alba (Lindl) by HPLC-DAD. Anal. Methods 2016, 8, 4867-4871. [CrossRef]

31. Majumder, P.L.; Roychowdhury, M.; Chakraborty, S. Thunalbene, a stilbene derivative from the orchid Thunia Alba. Phytochemistry 1998, 49, 2375-2378. [CrossRef]

32. Zhang, L.; Fang, Y.; Xu, X.F.; Jin, D.Y. Moscatilin induces apoptosis of pancreatic cancer cells via reactive oxygen species and the JNK/SAPK pathway. Mol. Med. Rep. 2017, 15, 1195-1203. [CrossRef] [PubMed]

33. Chen, C.A.; Chen, C.C.; Shen, C.C.; Chang, H.H.; Chen, Y.J. Moscatilin induces apoptosis and mitotic catastrophe in human esophageal cancer cells. J. Med. Food 2013, 16, 869-877. [CrossRef] [PubMed]

34. Chen, T.H.; Pan, S.L.; Guh, J.H.; Liao, C.H.; Huang, D.Y.; Chen, C.C.; Teng, C.M. Moscatilin induces apoptosis in human colorectal cancer cells: A crucial role of c-Jun $\mathrm{NH}_{2}$-terminal protein kinase activation caused by tubulin depolymerization and DNA damage. Clin. Cancer Res. 2008, 14, 4250-4258. [CrossRef] [PubMed]

35. Kowitdamrong, A.; Chanvorachote, P.; Sritularak, B.; Pongrakhananon, V. Moscatilin inhibits lung cancer cell motility and invasion via suppression of endogenous reactive oxygen species. BioMed Res. Int. 2013, 2013, 765894. [CrossRef] [PubMed]

36. Pai, H.C.; Chang, L.H.; Peng, C.Y.; Chang, Y.L.; Chen, C.C.; Shen, C.C.; Teng, C.M.; Pan, S.L. Moscatilin inhibits migration and metastasis of human breast cancer MDA-MB-231 cells through inhibition of Akt and Twist signaling pathway. J. Mol. Med. (Berl.) 2013, 91, 347-356. [CrossRef] [PubMed]

37. Kwon, J.; Lee, H.; Ko, W.; Kim, D.-C.; Kim, K.-W.; Kwon, H.C.; Guo, Y.; Sohn, J.H.; Yim, J.H.; Kim, Y.-C.; et al. Chemical constituents isolated from Antarctic marine-derived Aspergillus sp. SF-5976 and their anti-inflammatory effects in LPS-stimulated RAW 264.7 and BV2 cells. Tetrahedron 2017, 73, 3905-3912. [CrossRef]

Sample Availability: Not available.

(C) 2019 by the authors. Licensee MDPI, Basel, Switzerland. This article is an open access article distributed under the terms and conditions of the Creative Commons Attribution (CC BY) license (http://creativecommons.org/licenses/by/4.0/). 